\title{
Membangun Aplikasi Pengelolaan Surat Berbasis WEB pada SMK Negeri 1 Boyolali
}

\author{
Indri Ikasari ${ }^{\mathrm{a}, 1, *}$, Donna Setiawati ${ }^{\mathrm{a}, 2}$, Dwi Kristiani ${ }^{\mathrm{a}, 3}$ \\ ${ }^{a}$ Fakultas Ilmu Komputer, Universitas Boyolali, J1. Pandanaran No.405, Boyolali, 57315, Indonesia \\ ${ }^{1}$ d2k_indri@yahoo.co.id*; ${ }^{2}$ donna.setiawati@gmail.com; ${ }^{3}$ dwikristiani45@gmail.com \\ * Koresponsendi penulis
}

ARTICLE INFO

Article history

Menerima 3 Januari 2020

Revisi 11 Januari 2020

Diterima 30 Januari 2020

Kata Kunci

Aplikasi

Web

Surat

\section{ABSTRACT (10PT)}

The study entitled Building a web-based mail management application at SMK Negeri 1 Boyolali has the aim to develop a mail management information system in accordance with the administrative requirements of the archives section, simplifying the process of finding incoming and outgoing documents, structuring better mail archives. The research method used to solve various problems that occur is first to collect data. Data collected through observation, interviews and literature study. The next stage is the development of systems that use the waterfall method. This method consists of the stages of system planning (system engineering), needs analysis, design, program writing, testing and system maintenance. The result of his research is that the application is able to shorten the time in the process of managing incoming and outgoing mail, making it easier for users to manage agenda papers, making dispositions, and searching the archive of letters easier and faster.

This is an open access article under the CC-BY-SA 4.0 license.

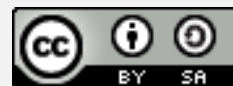

\section{Pendahuluan}

Surat adalah secarik kertas atau lebih yang berisi percakapan (bahan komunikasi) yang disampaikan oleh seseorang kepada orang lain, baik atas nama pribadi maupun organisasi / lembaga / instansi [1]. Dalam sebuah instansi surat merupakan alat komunikasi yang penting. Suatu instansi yang menerima surat masuk dan membuat surat keluar tidak hanya sebagai alat komunikasi, melainkan sebagai bukti otentik atas kegiatan yang telah dilakukan. Surat masuk adalah semua jenis surat yang diterima dari instansi lain maupun perorangan, baik yang diterima melalui pos, maupun yang diterima dari kurir dengan mempergunakan buku pengiriman.

Pengelolaan surat masuk merupakan salah satu tugas korespondensi dalam bidang kesekretariatan. Hal ini berarti pengelolaan surat masuk adalah prosedur pengelolaan suratsurat yang diterima oleh instansi dari pihak lain. Prosedur pengurusan surat masuk menurut [2] meliputi 1) Menyortir/memisahkan yaitu membuka surat-surat yang boleh dibuka oleh sekretaris hanya surat dinas kecuali dalam keadaan tertentu di mana atasan meminta membuka 
surat pribadinya; 2) Mengeluarkan dan memeriksa isi surat setelah dibuka, diperiksa alamat, nama pengirim, tanggal dan lampiran setiap surat; 3) Pencatatan surat setelah surat diberi cap tanggal, surat dicatat ke dalam buku agenda surat; 4) Membaca dan memberi catatan; 5) Menyampaikan surat kepada pimpinan; 6) Distribusi (disposisi) surat ke departemen lain; 7) Menjawab surat pada waktu pimpinan tidak ada ditempat. Sedangkan Surat keluar adalah surat yang dibuat oleh sebuah instansi untuk dikirim kepada instansi lain. Dalam pengelolaan surat keluar ada beberapa langkah penting yang harus dilakukan antara lain: pembuatan konsep surat, pengetikan surat, penandatanganan surat, pengiriman surat dan penyimpanan surat.

Oleh karena itu pengelolaan surat harus dilakukan setepat-tepatnya sehingga selalu dapat diikuti proses perkembangannya. Pendataan informasi surat membantu ketika arsip dapat ditemukan kembali dengan cepat dan tepat dikarenakan informasi yang lengkap terdapat pada dokumentasi yang dibuat Tujuan kearsipan adalah menyediakan data dan informasi dengan cepat dan tepat ketika diperlukan. Kearsipan merupakan dasar dari pemeliharaan surat, kearsipan mengandung proses penyusunan dan penyimpanan surat-surat sedemikian rupa, sehingga surat atau berkas tersebut dapat diketemukan kembali bila diperlukan.

Berdasarkan hasil observasi yang dilakukan di SMK Negeri 1 Boyolali, masih banyak kinerja tata usaha bagian pengarsipan kurang efisien karena masih menerapkan sistem pengarsipan konvensional yakni dengan cara ditulis dalam buku agenda. Hal tersebut merupakan permasalahan yang ada ketika ingin mencari kembali surat yang telah diarsipkan tersebut sulit didapat kembali karena tidak adanya pencatatan mengenai di mana surat itu disimpan dan diarsipkan. Oleh karena itu berdasarkan permasalahan diatas, diperlukan suatu sistem informasi yang mampu melakukan manajemen surat yaitu dalam pengelolaan surat masuk dan surat keluar meliputi agenda surat, penanganan disposisi surat dan pengarsipan surat serta sistem ini akan dibangun berbasis web. Sesuai perkembangan teknologi saat ini aplikasi manajemen surat berbasis website sangat dibutuhkan karena dapat meningkatkan produktifitas kerja suatu instansi. Tujuan penelitian ini adalah untuk mengembangkan sistem informasi manajemen surat sesuai dengan kebutuhan tata usaha bagian kearsiapan, mempermudah proses pencarian dokumen surat masuk dan surat keluar serta penataan arsip surat yang lebih baik. Dengan adanya sistem manajemen surat ini diharapkan mampu membantu untuk mempercepat dalam memperoleh kebutuhan informasi serta mewujudkan sistem manajemen surat secara sistematis.

\section{Tinjauan Pustaka}

Dalam penelitian ini, ada beberapa hasil dari penelitian terdahulu yang dapat dijadikan referensi yaitu sebagai berikut:

Penelitian yang dilakukan oleh [3] berjudul Sistem Informasi Manajemen Surat Berbasis Web Studi Kasus: Kantor Badan Pengelola Keuangan dan Aset Daerah Provinsi Jawa Timur. Tujuan penelitiannya untuk merancang dan membangun sistem informasi tata naskah dinas berbasis web pada Badan Pengelola Keuangan dan Aset Daerah Provinsi Jawa Timur. metode penelitian yang digunakan untuk menyelesaikan berbagai permasalahan yang terjadi meliputi studi pustaka, observasi, wawancara, analisis data dan system, perancangan system, pembuatan program, pengujian program, implementsi program. Penelitian menghasilkan aplikasi yang dapat mengelola surat masuk dan keluar sesuai alur yang ditetapkan, sehingga pengelolaan surat menjadi lebih efektif

Penelitian yang dilakukan oleh Oleh [4] berjudul Sistem Informasi Manajemen Surat (SMART) Pada Badan Kependudukan Dan Keluarga Berencana Nasional Provinsi Lampung, mempunyai tujuan untuk membantu kantor BKKBN Provinsi Lampung dalam memudahkan proses 
pengarsipan surat-surat menggunakan sistem yang terkomputerisasi, Sistem yang dibangun merupakan aplikasi berbasis web yang menggunakan PHP, CSS sebagai bahasa pemrograman dan MYSQL sebagai basis data, serta metodelogi dari Software Development Life Cycle (SDLC). Hasil pengujian menunjukkan bahwa fungsi-fungsi yang terdapat pada aplikasi berjalan dengan baik dan sesuai dengan kebutuhan dan rancangan serta sistem dapat berjalan dengan baik untuk meningkatkan kinerja yang di bagian Tata Usaha BKKBN Provinsi Lampung.

Penelitian yang dilakukan oleh [5] dengan judul Rancang Bangun Aplikasi Surat Masuk Dan Surat Keluar Berbasis Web Pada Kantor Asuransi Jiwa Kantor Layanan Administrasi Bandung, mempunyai tujuan yaitu 1) Membuat aplikasi surat masuk dan surat keluar yang dapat menyimpan berkas surat masuk secara aman serta berkas surat masuk yang disimpan dapat dilihat dan dicari sesuai dengan kebutuhan. 2). Membuat aplikasi laporan surat sesuai dengan tanggal atau waktu yang dibutuhkan serta menampilkan data-data surat yang sesuai dengan pengarsipan surat yang telah dimasukkan. 3). Membuat aplikasi untuk mengatasi masalah yang selama ini terjadi. Metode perancangannya menggunakan metode prototype, analisa dan desain sistem dengan Unified Modelling Language. Hasil penelitian berupa aplikasi untuk mempermudah user dalam pencatatan dan pengarsipan data surat masuk dan surat keluar.

\section{Metode Penelitian}

Metode penelitian yang dilakukan untuk menyelesaikan berbagai masalah yang terjadi adalah pertama melakukan pengumpulan data. Data dikumpulkan melalui observasi, wawancara dan studi kepustakaan. Tahap selanjutnya adalah pengembangan sistem yang menggunakan metode waterfall. Metode ini terdiri dari tahapan perencanaan sistem (rekayasa sistem), analisa kebutuhan, desain, penulisan program, pengujian dan perawatan sistem.

a. Tahap perencanaan yang dilakukan adalah menentukan lokasi penelitian dan waktu yang tepat untuk melakukan wawancara dengan pihak sekolah. Observasi dilakukan pada Sub Bagian Tata Usaha SMK Negeri 1 Boyolali yang beralamat di Jalan Perintis Kemerdekaan Boyolali. Waktu penelitian dimulai dari 1 Januari sampai dengan 30 Juni 2019.

b. Tahap Analisa Kebutuhan dilakukan dengan menganalisis sistem yang sedang berjalan. Berdasarkan hasil observasi dan wawancara, bahwa penanganan surat di sekolah ini masih menggunakan sistem manual sehingga sering terjadi keterlambatan dalam penanganan surat yang masuk maupun keluar dan sering kali arsip surat yang hilang. Oleh karena itu sistem yang diusulkan adalah pembuatan aplikasi manajemen surat berbasis web.

c. Tahap desain untuk mengambarkan interaksi admin dengan sistem dibuat menggunakan use case diagram seperti pada Gambar 1. Pada Gambar 1 dapat dijelaskan bahwa terdapat 3 (tiga) aktor yang terlibat dalam sistem yaitu Admin, Kepala Sekolah dan Guru. Fungsi yang ada pada sistem ini adalah pengolahan data pegawai, surat masuk, surat keluar, Agenda dan disposisi. Fungsi tersebut sesuai dengan kebutuhan yang diperlukan oleh sekolah tersebut dalam menangani manajemen surat. Sedangkan pada Gambar 2 yaitu relasi tabel yang terdiri dari tabel pegawai yang diberi disposisi, sifat surat, status surat, surat masuk, surat keluar, keterangan disposisi user, jabatan user dan tabel pegawai. 


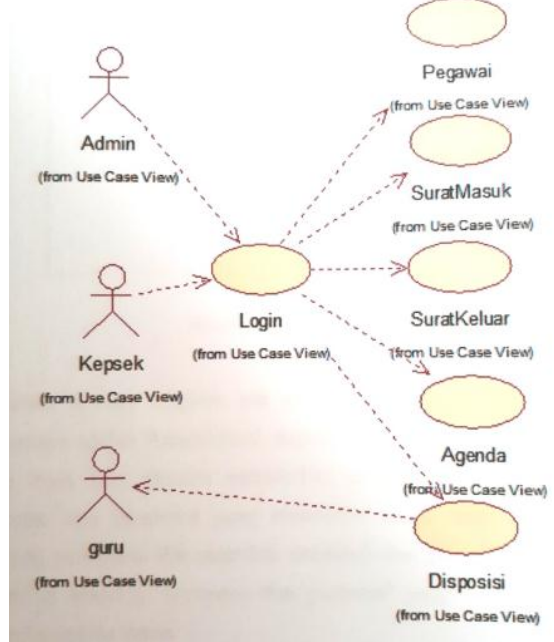

Gambar 1. Use Case Diagram

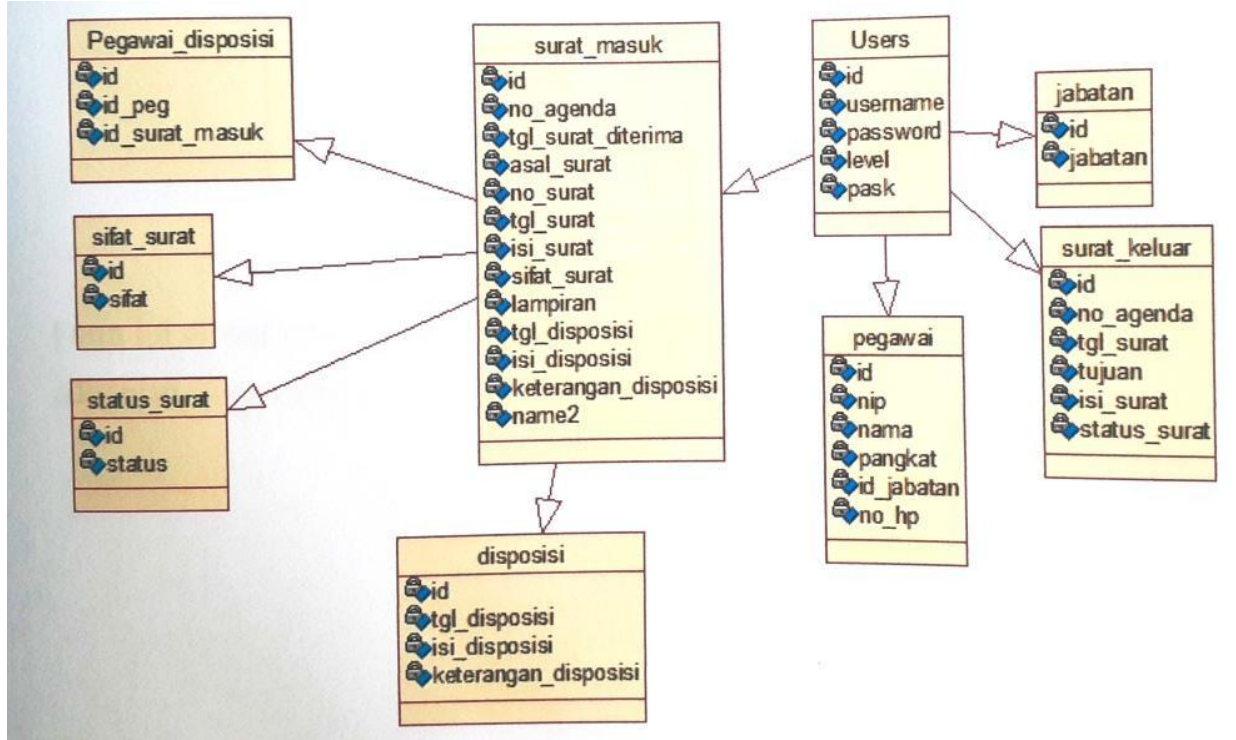

Gambar 2. Relasi Tabel

d. Tahap penulisan program dan implementasi dilakukan setelah tahap desain selesai. Dalam hal ini ditulis program sesuai dengan desain yang dibuat seperti form login, form disposisi, form penanganan surat masuk maupun surat keluar serta ouput atau laporan yang dibutuhkan.

e. Tahap pengujian dilakukan untuk menguji database maupun tombol-tombol yang disediakan telah berfungsi sesuai yang diharapkan. Serta menguji apakah sistem telah mampu memproses masukan dan keluar sebagai laporan seperti yang diinginkan.

f. Tahap Perawatan sistem adalah tahap terakhir yang harus tetap dilakukan jika pada saat dijalankan masih ada kesalahan atau error.

\section{Hasil dan Pembahasan}

Aplikasi manajemen surat pada SMK Negeri 1 Boyolali ini dibangun menggunakan Adobe Dreamweaver dan dijalankan menggunakan web server XAMMP. Hasil implementasi programnya menghasilkan halaman Login dan halaman menu utama. 


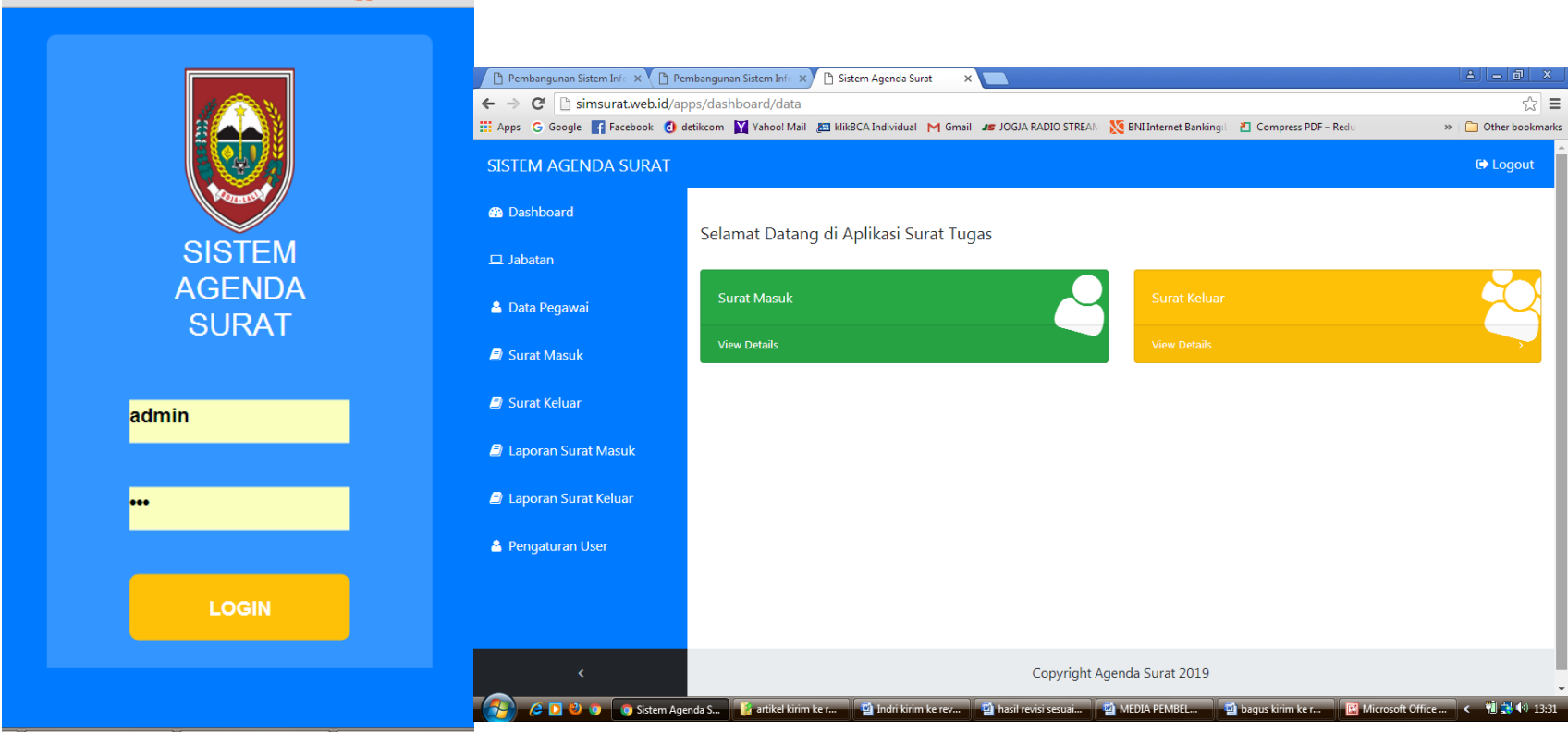

Gambar 3. Halaman Login

Gambar 4. Halaman Menu Utama

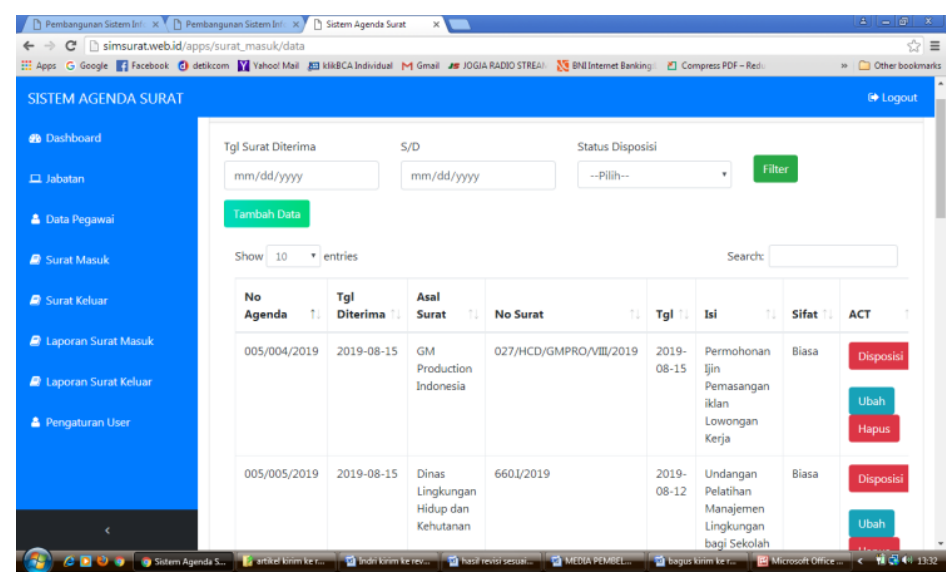

Gambar 5.. Halaman pengelolaan surat masuk dan keluar

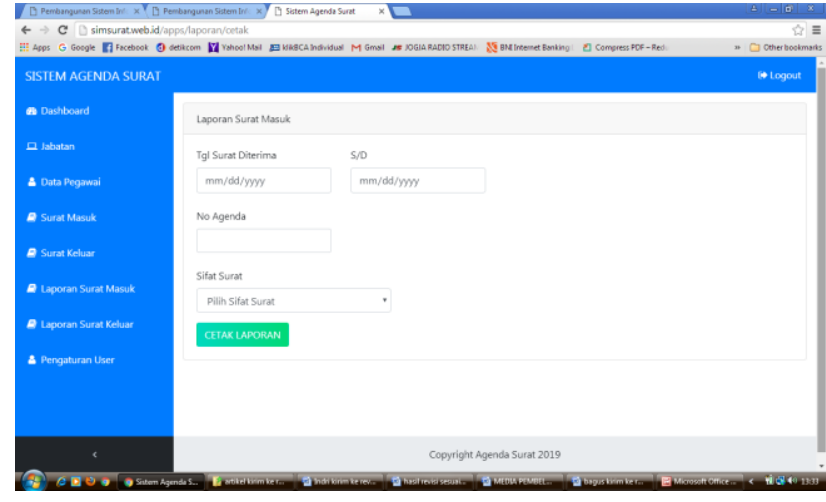

Gambar 6. Halaman Laporan

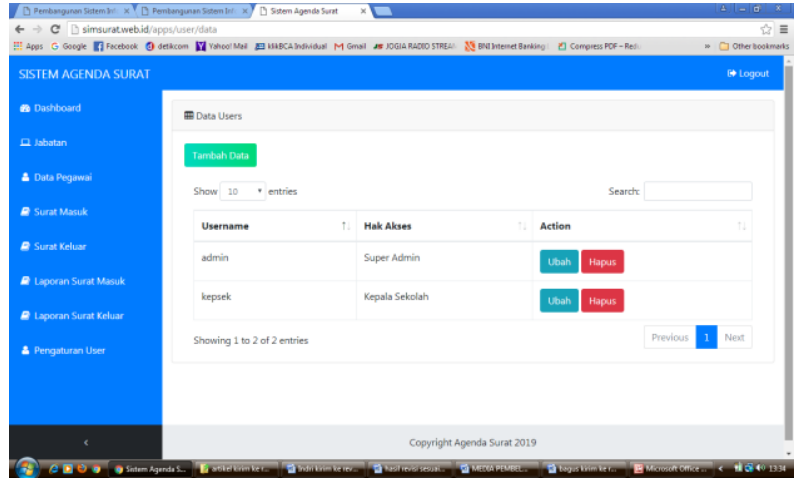

Gambar 7. Pengaturan User

Pada saat aplikasi dijalankan pertama kali maka yang akan muncul halaman login seperti pada Gambar 3. Pengguna harus memasukkan username dan password. Jika akun yang dimasukkan sudah benar maka akan masuk pada halaman menu utama seperti pada Gambar 4. Halaman menu 
utama berisi submenu Jabatan, Data pegawai, surat masuk, surat keluar, laporan surat masuk, laporan surat keluar dan pengaturan user.

a. Halaman data pegawai berfungsi untuk menambah, mengedit dan menghapus data guru atau data tenaga kependidikan.

b. Halaman surat masuk dan surat keluar seperti pada Gambar 5, digunakan untuk memasukan data agenda surat masuk, setelah data agenda surat di masukan admin dapat mengirim notifikasi ke kepala sekolah untuk dilakukan disposisi. Pada halaman surat masuk ini disertakan juga menu filter yang bisa digunakan untuk mencari data atau agenda surat yang telah dimasukkan ke sistem sebelumnya. Sedangkan halaman surat keluar, digunakan untuk memasukkan atau mengagendakan data surat keluar. Setelah surat dikirim maka admin akan mengirim notifikasi kepada Kepala Sekolah sebagai pemberitahuan bahwa surat telah diproses pengirimannya.

c. Halaman laporan surat masuk dan surat keluar seperti pada Gambar 6, digunakan untuk pencetakan laporan surat masuk dan surat keluar yang dapat di sesuaikan dengan kubutuhan, yaitu dapat menentukan laporan surat berdasarkan tanggal, nomer agenda dan sifat surat.

d. Halaman Pengaturan user seperti pada Gambar 7, untuk menambah, mengubah dan menghapus user

Dengan adanya aplikasi manajemen surat ini pengelolaan surat masuk dan surat keluar sudah lebih baik karena proses penanganan surat sudah diintegrasikan dalam sistem sehingga pemrosesan lebih cepat terdistribusikan kepada sasaran, serta tidak ada lagi surat yang tidak ditindaklanjuti karena semua surat masuk maupun keluar telah dimasukkan kedalam sistem yang akan terdeteksi oleh sistem. Dalam hal pencarian surat sudah lebih cepat dan tepat karena dalam aplikasi ini sudah dilengkapi fasilitas pencarian. Pengguna dapat mencari surat yang diinginkan dengan menuliskan kata kunci pencarian berdasarkan tanggal, alamat surat maupun isi surat kemudian menekan tombol search.

Pengarsipan surat dengan metode konvensional membutuhkan peralatan yang cukup besar karena penyimpanan arsip minimal 5 tahun terakhir, sehingga untuk menyimpan arsip surat dalam kurun waktu tersebut membutuhkan filing cabinet atau almari arsip serta ruangan yang luas. Dengan adanya aplikasi yang dibuat ini, surat sudah disimpan dalam bentuk file dan tersimpan dalam database yang aman sehingga tidak perlu membutuhkan peralatan seperti lemari arsip lagi.

Hasil penelitian ini mendukung penelitian yang telah dilakukan oleh [3], [4] dan [5] yaitu aplikasi yang dibuat untuk mengelola surat masuk dan keluar sesuai alur yang ditetapkan dan pengelolaan surat menjadi lebih efektif.

\section{Kesimpulan}

Berdasarkan hasil penelitian dan pembahasan yang telah diuraikan sebelumnya maka dapat disimpulkan bahwa aplikasi manajemen surat ini mampu membantu Staf Tata Usaha khususnya dibidang agendaris dalam pengelolaan surat dan mampu memberikan informasi tentang surat serta disposisi tindaklanjutnya. Selain itu aplikasi manajemen surat ini mampu memfasilitasi dan memudahkan dalam penemuan kembali arsip surat di SMK Negeri 1 Boyolali. Pengembangan selanjutnya diperlukan agar aplikasi berjalan lebih baik. Beberapa saran untuk pengembangan lebih lanjut antara lain: menunjuk pegawai khusus untuk menangani kegiatan persuratan yang mampu menguasai IT, perlu ditambahkan fasilitas backup data pada aplikasi manajemen surat ini untuk mencegah terjadinya kerusakan perangkat lunak, perangkat keras, maupun kesalahan pengguna, agar keamanan data aplikasi tetap terjaga.

\section{Ucapan Terima Kasih}


Ucapan terimakasih diberikan kepada Kepala Sekolah dan bagian tata usaha SMK Negeri 1 Boyolali yang telah memberikan kesempatan dan dukungan untuk melakukan kegiatan penelitian ini.

\section{Daftar Pustaka}

[1] Suryani, Nanik, Agung Kuswantoro, dan Sularso Mulyono. 2015. Korespondensi Bahasa Indonesia. Yogyakarta : Graha Ilmu.

[2] Sedianingsih, Nieke P. Suetanto, Farida Mustikawati. 2010. Teori dan Praktik Administrasi Kesekretariatan. Jakarta : Kencana.

[3] Harliawan Hertanto. 2016. Sistem Informasi Manajemen Surat Berbasis Web, Skripsi Program Studi Sistem Informasi, Fakultas Ilmu Komputer Universitas Narotama Surabaya. http://karyailmiah.narotama.ac.id/files/Sistem\%20Informasi\%20Manajemen\%20Surat\%20Berba sis $\% 20 \mathrm{Web} \% 20$ Studi $\% 20$ Kasus\%20Kantor\%20Badan\%20Pengelola\%20Keuangan $\% 20$ dan $\% 20$ Aset\%20Daerah\%20Provinsi\%20Jawa\%20Timur.pdf, diakses tanggal 30 Agustus 2019.

[4]Dila Nurila, 2017. Sistem Informasi Manajemen Surat (SMART) Pada Badan Kependudukan Dan Keluarga Berencana Nasional Provinsi Lampung, Skripsi Fakultas Matematika Dan Ilmu Pengetahuan Alam, Universitas Lampung, Lampung

[5] Irwin S, Rina I, Verra T.M. 2018. Rancang Bangun Aplikasi Surat Masuk Dan Surat Keluar Berbasis Web Pada Kantor Asuransi Jiwa Kantor Layanan Administrasi Bandung. Skripsi STMIK Atma Luhur, Pangkal Pinang 